\title{
Improving the application of information and communication technologies in the activities of prevention of offenses
}

\section{Svetlana SELIMANOVA ${ }^{1}$ Umid TALLIBAYEV $^{2}$}

Academy of the Ministry of Internal Affairs of the Republic of Uzbekistan

\begin{tabular}{l} 
ARTICLE INFO \\
\hline Article history: \\
Received January 2021 \\
Received in revised form \\
15 January 2021 \\
Accepted 20 February 2021 \\
Available online \\
7 March 2021 \\
\hline Keywords: \\
Information and \\
communication technologies \\
Internal affairs bodies \\
Crime prevention \\
Forces and means \\
Administrative and legal \\
norms \\
System \\
Citizens' rights
\end{tabular}

\section{ARTICLE INFO}

Article history

Received January 2021

15 January 2021

Accepted 20 February 2021

Available online

Keywords:

Information and

communication technologies

Administrative and legal

System

Citizens' rights

\begin{abstract}
The article analyzes the issues of improving the use of information and communication technologies in the prevention of offenses on the basis of studying the norms of national legislation, the opinions of domestic and foreign scientists. It is noted that today, cardinal changes in the information sphere at the global level are carried out through the rapid development and dissemination of new information and communication technologies. An increasing influence on the economy, politics, international relations and culture is exerted by the development and improvement of global networks, which open up endless possibilities of direct communication between people in real time. All these advances in the information field create the preconditions for moving towards a completely new type of society - the information society and information space. On the basis of the study, scientifically grounded proposals and recommendations were formulated aimed at improving this area.
\end{abstract}

\section{1-1415/C 2021 in Science LLC.}

This is an open access article under the Attribution 4.0 International (CC BY 4.0) license (https://creativecommons.org/licenses/by/4.0/deed.ru)

\footnotetext{
${ }^{1}$ Doctor of Law, Professor, Academy of the Ministry of Internal Affairs, the Republic of Uzbekistan, Tashkent, Uzbekistan

E-mail: Selimanova@inbox.uz

${ }^{2}$ Lecturer, Department of Administrative Law, Academy of the Ministry of Internal Affairs of the Republic of Uzbekistan, Tashkent, Uzbekistan

E-mail: tallibayevumid@gmail.com
} 


\section{Хуқуқбузарликлар профилактикаси фаолиятида ахборот- коммуникация технологияларидан фойдаланишни такомиллаштириш}

\author{
Калит сўзлар: \\ Информационно- \\ коммуникацион \\ технологиялар \\ Ички ишлар органлари \\ Хукуқбузарликлар \\ профилактикаси \\ Куч ва воситалар \\ Маъмурий-хуқуқий \\ нормалар \\ Тизим \\ Фуқароларнинг хуқуқлари
}

\section{АННОТАЦИЯ}

Мақолада миллий қонунчилик нормалари, миллий ва хорижий олимларнинг фикрларини ўрганиш асосида хуқуқбузарликлар профилактикасида информационкоммуникацион технологияларни қуллашни такомиллаштириш масалалари тахлил қилинган.

Бугунги кунда информацион сохада глобал даражада туб ўзгаришлар янги информацион-коммуникацион технологияларнинг шиддат билан ривожланиши ва тарқалиши орқали намоён бўлмоқда. Глобал тармоқларнинг иқтисодиётга, сиёсатга, халқаро муносабатларга ва маданиятга таъсири тобора ортиб бориб, улар инсонларнинг реал вақт режимида ўзаро муносабатларга киришиши учун чексиз имкониятларни пайдо қилмоқда. Информацион сохадаги ушбу ютуқлар жамиятнинг мутлақо янги шакли - информацион жамият ва информацион макон сари харакат бошланганлигини англатади.

Амалга оширилган тадқиқот натижаларига кўра мазкур сохани такомиллаштиришга қаратилган илмий асосланган таклиф ва тавсиялар шакллантирилган.
Совершенствование коммуникационных профилактики правонарушений применения технологий
B

информационно-

\footnotetext{
Ключевые слова:

Информационно-

коммуникационные

технологии

Органы внутренних дел

Профилактика

правонарушений

Силы и средства

административно-

правовые нормы

Система

Права граждан
}

\section{АННОТАЦИЯ}

В статье на основе изучения норм национального законодательства, мнений отечественных и зарубежных ученых проанализированы вопросы совершенствования применения информационно-коммуникационных технологий в деятельности профилактики правонарушений. Отмечается, что на сегодняшний день кардинальные изменения в информационной сфере на глобальном уровне осуществляются посредством стремительного развития и распространения новых информационно-коммуникационных технологий. Возрастающее влияние на экономику, политику, международные отношения и культуру оказывают развитие и совершенствование глобальных сетей, которые открывают безграничные возможности непосредственного общения между людьми в режиме реального времени. Все эти достижения в информационной сфере создают 


предпосылки для движения к совершенно новому типу
общества - информационному обществу
информационному пространству.
На основе проведенного исследования сформулированы
научно-обоснованные предложения и рекомендации
направленные на совершенствование данной сферы..

\section{INTRODUCTION}

The development of information technologies in the activities of internal affairs bodies today becomes an objective necessity for the timely and prompt consideration of cases of administrative offenses.

Nowadays, more and more often there is a need for technological and legal interaction of the subjects of modern society as an information society. The development of the information society in the Republic of Uzbekistan emphasizes the special importance of administrative and legal regulation in creating the necessary pace and quality of development and functioning of the information society.

As the head of state noted «... in the conditions of current globalization, economic competition is becoming more and more acute, information and terrorist threats are intensifying»[1].

In accordance with the Strategy of Actions for the Further Development of the Republic of Uzbekistan in 2017-2021, one of the directions is «... the creation of effective mechanisms for the introduction of scientific and innovative achievements into practice ..»[2].

The development of administrative processes in the state is significantly modernized in connection with the development of information technologies, the development of normative support for information relations in society and the improvement of administrative and legal regulation of the use of information technologies provides an increase in the efficiency of management in the context of administrative and legal reform.

\section{MEANS AND METHODS OF RESEARCH.}

It should be noted that during the development of advanced technical means, information and communication technologies and systems used in almost all spheres of human life, the internal affairs bodies, namely the Main Department for the Prevention of Offenses, began to widely use information systems and digital technologies to carry out their official duties and before them tasks, as well as to protect the rights and freedoms of man and citizens of our country.

According to Professor A.K. Rasulev, the modern stage of development of society is characterized by the increasing role of the information sphere, which is a collection of information, as well as a system for regulating the resulting social relations [3, C.15].

In accordance with the Decree of the President of the Republic of Uzbekistan «On measures to radically improve the activities of crime prevention units of the internal affairs bodies», one of the main functions of the Main Directorate of crime prevention units of the internal affairs bodies is to ensure the introduction of modern forensic technology, information and communication technologies, -reference databases, making suggestions for improving methods of preventing offenses [4]. 
As noted by the foreign scientist Kovacheva H.H. the information function of the state is to promote the formation of an information society, improve the quality of life of the population through the comprehensive introduction of information technologies into the life of society and the state, while creating conditions for the full protection of the rights of all subjects involved in the implementation of information policy [5, C.150-154].

Note that information technology - translated from the Greek language, the word technology means «skill», «skill», that is, these are certain processes, based on this, «information technology» is a process that uses the means and methods of collecting, processing and transmitting data (primary information) making it possible to extract new qualitative information about the state of an object, process or phenomenon (information product) $[6$, C.456].

The use of information and communication technologies and systems is today considered as one of the main ways to modernize the system of internal affairs bodies. This is due not only to the development of technology and technology, but also, first of all, to the changes that are caused by the development of the information society, in which information and the ability to work with it become the main value. Accordingly, one of the main tasks of the modern system of internal affairs bodies is the development of projects and programs that contribute to the formation of a person in modern society. Informatization of the internal affairs bodies should be considered as one of the important means of achieving this goal. This refers to the solution of a number of sequential tasks: technical equipment, the creation of didactic tools, the development of new technologies in solving crimes, offenses, etc., which determine the stages of the modernization process.

According to Ivanov E.Yu. the information and communication policy of the state is a substantive, stable system of organizational and legal forms and means of influence (stimulation, restriction and control) on the functioning of the information and communication sphere [7, C.20].

As the results of the work show, they directly depend on the quality of information support, since the main task of practitioners in the investigation, disclosure and prevention of crimes is in one way or another to obtain the necessary information.

The main role in the information support of law enforcement agencies is played by the accounts used to register primary information about crimes, as well as about the persons who committed them. The registration of persons is used to obtain information that helps in the prevention, disclosure and investigation of crimes, to establish the identity of unknown persons and the belonging of seized property, to search for criminals.

It should be noted, taking into account the peculiarities of the processes of considering cases of administrative offenses, associated precisely with the accumulation and implementation of a certain amount of orienting and evidentiary information, it becomes obvious the need for the broadest introduction of modern information technologies in law enforcement.

It should be especially emphasized the importance of considering cases of administrative offenses in accordance with Article 305 of the Code of the Republic of Uzbekistan on Administrative Responsibility, which is characterized by a shortage of time to consider offenses, within a day, three days and within five days. This process is associated with the high dynamism of the efficiency of receiving, processing and implementing actual data depends on the timeliness of obtaining information. In the internal affairs bodies, the introduction of new information and communication 
technologies and scientific advanced technical means is based on the construction on the basis of modern computers of local, regional and national branch information and computer networks, contributing to the further improvement of the information support of the internal affairs bodies.

So, the information used in the internal affairs bodies carries information about the state of crime and public order in a certain served administrative territory, about the activities of the bodies and divisions themselves, as well as about the forces and means available. In the units on duty, from operational workers, preventive maintenance inspectors, investigators, experts of forensic departments, other divisions, on documents of the initial stage, in accounting journals and on other media, data arrays of operationalsearch and operational reference purposes are collected.

Law enforcement agencies use the worldwide Internet information system to carry out tasks assigned to the internal affairs bodies. Social networks have an important role in society, the conditions allowing criminals to commit various types of crimes, and also enable law enforcement agencies to receive reliable information about the persons involved in the case. When investigating crimes, employees of the internal affairs bodies have the right, upon receipt of a permit (order), and in exceptional cases and without the sanction of the prosecutor, followed by informing him within twenty-four hours, to watch the recordings from CCTV cameras located near the crime scene. Also, the internal affairs bodies use information technology not only to search, record, investigate and solve criminals and crimes, but also to facilitate the service of the population.

Currently, citizens and organizations can use a single window of public services provided by the internal affairs bodies of the Republic of Uzbekistan in electronic form. One of the services in demand among citizens is to receive information on administrative offenses in the field of road traffic, provided free of charge.

In the context of information and technical progress and information technologies, when they are so in demand, they are a key factor in optimizing the activities of internal affairs bodies as part of the executive branch.

\section{FINDINGS:}

Currently, the main directions of state information and communication policy are: creation and development of systems and networks of informatization; formation and protection of information resources of the state; ensuring the interests of national security in the field of informatization; ensuring the unity of state standards in the field of informatization; formation and implementation of a unified state scientific, technical and industrial policy; creation and improvement of a system for attracting foreign investment and a mechanism to stimulate non-state structures in the development and implementation of informatization projects.

Thus, the state policy of the Republic of Uzbekistan in the field of formation and use of legal information resources and the provision of these resources to the needs of social and economic development of the country is carried out taking into account the interests, trends of international cooperation in the field of legal informatics, the real possibilities of the informatization industry in a market economy.

\section{References:}

1. Message from the President of the Republic of Uzbekistan Shavkat Mirziyoyev to

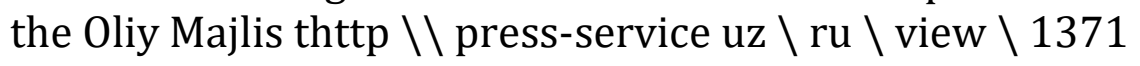


2. Decree of the President of the Republic of Uzbekistan "On the Strategy of Actions for the Further Development of the Republic of Uzbekistan" dated February 7, 2017 No. UP 4947

3. 3. Rasulev A.K. Some issues of improving criminal law and criminological measures to combat crimes in the field of information technology and security $\backslash \backslash$ Monograph, T., 2017, p. 15

4. By the Decree of the President of the Republic of Uzbekistan "On measures to radically improve the activities of the departments for the prevention of offenses of the internal affairs bodies" dated April 18, 2017, No. PP-2896

5. Kovacheva H.H. On the relationship between the concepts of "information services" and "state electronic services" // Actual problems of law in Russia and the CIS countries - 2012: materials of the XIV International scientific-practical conference with elements of a scientific school. S. 150-154.

6. S.I. Ozhegov and N.Yu. Shvedova Explanatory Dictionary of the Russian Language M., 2010, p. 456

7. Ivanov E.Yu. Information in economics: theoretical aspect. Abstract dissertation. .kand. economic sciences. Novosibirsk, $2000.20 \mathrm{p}$ 